Article

\title{
The Future of Money and the Central Bank Digital Currency Dilemma
}

\author{
Carlos Viñuela ${ }^{1,2,+}$, Juan Sapena ${ }^{3, *,+} \mathbb{D}$ and Gonzalo Wandosell ${ }^{4,+} \mathbb{C}$ \\ 1 Doctoral School, Catholic University of Murcia, 30001 Muricia, Spain; cjvinuela@alu.ucam.edu \\ 2 Bank of Spain, 28014 Madrid, Spain \\ 3 Economics and Business Department, Catholic University of Valencia, 46001 Valencia, Spain \\ 4 Faculty of Business and Law, Catholic University of Murcia, 30001 Muricia, Spain; gwandosell@ucam.edu \\ * Correspondence: juan.sapena@ucv.es \\ + These authors contributed equally to this work.
}

Received: 30 October 2020; Accepted: 18 November 2020; Published: 20 November 2020

check for updates

\begin{abstract}
In this paper we set out a three-pillar monetary-financial framework to (i) analyze, categorize and compare past, current and emerging means of payment; to (ii) capture their creation and destruction processes through sectoral balance sheet dynamics; and to (iii) identify the inherent risks to the current monetary-financial system, also known as the fractional reserve banking system. These risks, which stem from sudden shifts in money demand and supply, are as follows: (I) risk of a cashless society; (II) risk of structural bank disintermediation; (III) risk of systemic bank runs; (IV) risk of currency substitution; and (V) risk of economic and financial bubbles. This framework will guide the assessment of the central bank digital currencies (CBDC), which are considered as the next step in monetary evolution. We will analyze two large groups of CBDC proposals: (i) proposals aimed at complementing cash and bank deposits; and (ii) proposals aimed at replacing all bank deposits with CBDCs. We find that once CBDCs are issued in both sets of proposals, there is always a trade-off between low levels of (I), (IV), (V), risks and high levels of (II) risk. This trade-off could also be defined as the CBDC dilemma, which states that in most CBDC proposals it is impossible to have both of the following at the same time: (1) low levels of (I), (IV) and (V) risks; and (2) low levels of (II) risk. Finally, we suggest that further research on CBDCs should focus on the second group of proposals on a phase-in basis in order to also mitigate the structural bank disintermediation risk and hence to overcome the CBDC dilemma.
\end{abstract}

Keywords: CBDC; structural bank disintermediation; money creation; fractional reserve banking; full reserve banking

\section{Introduction}

"Everyone can create money; the problem is to get it accepted".

-Hyman Minsky

The world is entering a new monetary era. For nearly 200 years central banks have provided cash as a credit-risk-free means of payment, but now is significantly declining in a few countries and at a not too distant future we might face cashless societies. New digitalized entrants into payment services and financial intermediation are also reshaping the monetary-financial landscape. Central banks properly addressed the rise of private digital currencies such as Bitcoin with just a study approach, since they do not pose any risk to the current monetary-financial system. However, Facebook's announcement last year that it plans to launch its private-fiat-backed digital currency poses systemic risks to both the financial system and the monetary sovereignty of most economies. Furthermore, the dysfunctions 
of the current monetary-financial system that materialized in the Great Depression have again triggered another economic crisis, the so-called Great Recession in 2008, whose consequences are unfortunately still being felt today. From both academic and institutional fields, credit booms and over-indebtedness have been identified as the main causes of financial bubbles and economic crises, but few have focused on how all these booms are financed. In the 1930s, Irving Fisher and many of its contemporaries identified the current fractional reserve banking system, in which commercial banks create deposits by making loans, as the main cause of the economic cycle. Nowadays, these studies have been revisited and they are focusing on sudden increases and contractions of bank credit to the real sector, which are fueled by the out of nothing bank deposit creation, during the first two decades of the new millennium [1-3]. Central banks and academics have identified several risks stemming from the decline in cash usage, the rise of private digital currencies and the dysfunctions of the fractional reserve banking system. Over the past five years, CBDCs are being seen as a means of payment that could limit these risks and offer other potential benefits. Among the benefits of issuing CBDCs, the following has been highlighted: (i) foster financial inclusion of unbanked and underbanked households and companies; (ii) enrich the central bank's monetary policy toolkit, by strengthening the pass-through of policy rate changes, by addressing the zero lower bound (ZLB) constraint on interest rates and by capturing the fiscal revenue from money creation, namely, the seigniorage; (iii) ensure that public money remains the most demanded unit of account in the face of private digital currencies; (iv) allow general public to make payments and save in a credit-risk-free money; and (v) improve financial and macroeconomic stability by mitigating recurring economic cycles. Domestic-retail CBDCs [4] would be a new form of money which would allow households and companies to use account-based money issued by central banks for the first time in monetary history. The CBDC term was coined in 2016 [5] and since that date the debate has significantly increased and currently is at the top of the policy agenda [6,7] (Auer, Giulio and Frost, 2020) [8]. The fact that both central banks and academics are considering different design features for their CBDC issuances has enriched the debate [9]. The Great Lockdown has not postponed the CBDC debate but has boosted it because CBDCs could be technologically designed as a touchless means of payment [10], substituting frequently-touched payment instruments, such as cash and credit cards, which increase the probability of the viral-COVID-19 transmission. On the other hand, CBDCs might challenge the current fractional reserve banking system so central banks must carefully weigh the costs of issuing CBDCs and identify the associated trade-offs.

The main risk posed by a CBDC issuance is the risk of structural bank disintermediation, which consist of the shrinking of the commercial banks' balance sheet due to a large-scale migration from bank deposits to CBDCs. Currently, CBDC proposals are focused on: (i) the technological designs, weighting the benefits and costs of anonymous-based vs. nominative-based formats and conventional-based vs. distributed ledger technology (DLT)-based payment systems; and (ii) how to mitigate the structural bank disintermediation risk posed by a passive CBDC issuance, since the same technological design features of bank deposits and CBDC and the low-interest rates environment entail a strong competition between these two means of payment. In order to limit the structural bank disintermediation risk, some proposals have designed CBDC issuances with the following two economic features: (i) an unattractive interest rate, such as a non-remunerated or an under-remunerated CBDC; and (ii) a hybrid issuance rule with quantitative limits on CBDC demand.

In Section 2 of this paper we first set out a three-pillar monetary-financial framework which aims at creating a sound understanding of the functioning of the current fractional reserve banking system. We see this conceptual research as more adequate and relevant than an empirical approach, since the lack of data hampers the ability to draw conclusions regarding the CBDCs' impacts on the economy.

In Section 2.1 we develop the first pillar of the framework, a monetary-financial taxonomy which comprises four different means of payment with the following six design features: two related to the technology, the format of the mean of payment (I) and the payment system (II); and four regarding economic features, the value of the monetary asset (III), its nature (IV), the issuance (V) and the rate of interest (VI). All these design features drive the shifts in money demand. In Section 2.2 we study 
the second pillar, which is the supply of the four means of payment through sectoral balance sheet dynamics. We focus on the creation and destruction processes of bank deposits, which in today's economies comprise nearly all the money supply and are the main cause of the economic cycle due to their sudden increases and contractions.

The third pillar of the monetary-financial framework is developed in Section 2.3, in which we identify five inherent risks to the current fractional reserve banking system. These risks stem from sudden shifts in money demand and supply. From the demand side, we identify two categories depending on whether the shifts are driven by technological features, such as substitutions of less advanced means of payment for new ones, or by economic features, such as replacements of one sovereign unit of account by another. Technological-driven shifts could materialize the risks of a (I) cashless society, (II) structural bank disintermediation and (III) systemic bank runs, while economic-driven shifts could trigger a risk (IV) of currency substitution. Regarding the sudden shifts in money supply, they are explained by commercial banks' ability to create new bank-deposit money in the process of bank lending, which poses the risk of $(\mathrm{V})$ economic and financial bubbles.

Given the assumption that the sudden shifts in money demand and supply pose these five risks to the current fractional reserve banking system, we see CBDC issuances as a powerful tool to limit these risks. In Section 3 we assess the effectiveness of several domestic-retail CBDC proposals in mitigating the five abovementioned risks through sectoral balance sheet dynamics. These CBDC proposals are classified into the following two categories: (3.1) CBDCs as new means of payment that would complement cash and bank deposits; and (3.2) CBDCs as new means of payment that would replace all bank deposits.

In conclusion, we find that in the first group of proposals, once CBDCs are issued there is always a trade-off between low levels of (I), (IV), (V), risks and high levels of (II), (III) risks, due to the high degree of demand-side substitutability between bank deposits and CBDCs. This could also be defined as the CBDC dilemma, which states that in CBDC proposals aimed at complementing cash and bank deposits it is impossible to have both of the following at the same time: (1) low levels of (I), (IV) and (V) risks; and (2) low levels of (II) and (III) risks. With regard to the second group of proposals, there is a trade-off between a high level of (II) risk and low levels of the others risks and hence the CBDC dilemma here would be between low levels of (I), (III), (IV) and (V) risks and low levels of (II) risk. We suggest that further research on CBDCs should focus on this second group of proposals, which puts forward CBDC transitions from a fractional reserve banking system to a full reserve banking system, with a phase-in approach aimed at also mitigating the risk of structural bank disintermediation and hence to overcome the CBDC dilemma.

\section{A Three-Pillar Monetary-Financial Framework}

\subsection{The First Pillar: A Monetary-Financial Taxonomy to Compare and Classify Different Means of Payment}

In modern economies, people demand five means of payment with different features. In Table 1 we show a monetary-financial taxonomy based on the existing work of the International Monetary Fund [9] and the Bank of International Settlements [4]. These five means of payment are cash, bank deposits, e-money, stablecoins and virtual currencies. From a technological perspective we distinguish the format and the payment system as key design features, while from an economic perspective we identify the value, the nature of the means of payment, the issuance and the rate of interest. All these design features drive the shifts in money demand. 
Table 1. The monetary-financial taxonomy with the five means of payments plus central bank reserves.

\begin{tabular}{|c|c|c|c|c|c|c|}
\hline $\begin{array}{l}\text { Design } \\
\text { Features }\end{array}$ & Cash & Reserves & $\begin{array}{c}\text { Bank } \\
\text { Deposits }\end{array}$ & $\begin{array}{c}\text { Electronic } \\
\text { Money }\end{array}$ & $\begin{array}{l}\text { Stablecoins } \\
\text { (LIBRA V1.0) }\end{array}$ & $\begin{array}{c}\text { Virtual } \\
\text { Currencies } \\
\text { (Bitcoin) }\end{array}$ \\
\hline Format & Object-based & Account-based & Account-based & Account-based & Account-based & Account-based \\
\hline $\begin{array}{l}\text { Payment } \\
\text { System }\end{array}$ & N/A & Direct Ledger & $\begin{array}{l}\text { Indirect } \\
\text { Ledger }\end{array}$ & $\begin{array}{l}\text { Indirect } \\
\text { Ledger }\end{array}$ & $\begin{array}{l}\text { Direct Ledger } \\
\text { (DLT) }\end{array}$ & $\begin{array}{c}\text { Direct Ledger } \\
\text { (DLT) }\end{array}$ \\
\hline Value & EUR & EUR & EUR & EUR & $\sim \sim L B R$ & BTC \\
\hline Nature & Real asset & Real asset & Claim & Claim & Both & Real asset \\
\hline Issuance & Passive & Active & Active & Passive & Both & Active \\
\hline $\begin{array}{l}\text { Interest } \\
\text { bearing }\end{array}$ & $\mathrm{NO}$ & YES & YES & $\mathrm{NO}$ & Both & $\mathrm{NO}$ \\
\hline
\end{tabular}

The first feature defining a means of payment is the format, which can be either object-based or account-based. The object-based format is tangible and allows anonymous transactions between users, as is currently the case with cash. On the other hand, account-based means of payments consist of a data registration in which every user is recorded in a ledger along with its amount of money and its flow of funds.

Any account-based means of payment has a payment system which involves two components. The first component is the ledger, which can be based either on an indirect ledger approach, for example, bank deposits and e-money, or on a direct ledger approach, for example, Bitcoin and other digital currencies based on Distributed ledger technology (DLT). Moreover, the ledger could be designed either in an anonymous basis, for example, Bitcoin, or in a nominative basis, for example, bank deposits and e-money. The second component is payment services, which mainly involves three phases: the processing of the information, in other words, the transfer of payment data between users' accounts and the updating of the ledger, the clearing and the settlement processes. When these two components are based on digital technologies, these means of payment are categorized as digital currencies.

The current monetary-financial system is mainly based on an indirect ledger approach in which commercial banks issue on-balance-sheet ledgers, in other words, bank deposits. Because in this indirect ledger approach users transfer claims to one another, the payment system needs clearing and settlement processes, such as the market-based deferred-net-settlement networks, in other words, wholesale interbank clearinghouses such as Visa Europe, and the public real-time gross-settlement networks, such as TARGET2. E-money issuers create alternative payment systems based on indirect ledgers, also known as closed loop networks, in which both the payer and the payment recipient must have an account to transfer the funds. In these closed loop networks, such as PayPal and TransferWise, the only payment service needed is the processing of the information. In DLT-based ecosystems, such as Bitcoin and the Libra Proposal, there is a sole and direct ledger replicated in each member, which jointly participate in the processing of the information.

The economic perspective of this taxonomy is reflected in the remaining features: the nature of the means of payment, its value, the issuance and the rate of interest. The current monetary-financial system has two levels. In the second level intermediaries issue claim-like instruments as means of payments, such as bank deposits and e-money, which are financial assets that poses an obligation for the issuer to redeem these instruments for cash or bank deposits. Nowadays the most demanded means of payments are bank deposits, which are fractional-backed because commercial banks' assets are mainly comprised of long-term debt and loans. The issuances of e-money are also fractional backed since the e-money institutions' assets are comprised of short-term debt and cash equivalents. The first level or anchor of the current monetary-financial system is cash issued by the central bank, which is a real-asset-like instrument because its issuance does not pose and obligation for the central bank to redeem. Reserves are means of payments issued by central banks, convertible into cash and restricted to commercial banks and the government. 
The price of any goods in the economy is determined by the subjective preferences of the parties involved in an exchange. The means of payment are not an exception and these subjective preferences, in other words, money demand, steam from their effectiveness in fulfilling the three functions of money $[11,12]$.

When we talk about the value or the price of a means of payment we mainly refer to an abstract unit of account. The value of the unit of account is represented by the purchasing power, which can be measured by inflation and exchange rates indexes. During the 5000 years of monetary history, money has gradually evolved from having an intrinsic value, in other words, the use value of gold, silver and other commodities to a monetary value, also known as fiat value, in other words, the value guaranteed by public authorities or private institutions. Nowadays, all means of payment only have a monetary value and hence money demand is volatile and directly depends on trust that public authorities keep this current monetary value stable through monetary policy rules implemented by independent central banks. Changes in the value of money are mainly reflected in changes in inflation rates. Inflation is the result of both real and monetary phenomena. From the real side, we can distinguish: (i) a demand-pull inflation due to excess aggregate demand, which could be driven by an over-issuance of money, which in turn could be driven either by fiscal deficits or by bank credit; and (ii) a supply-side or cost-push inflation, which occurs when adverse shocks in aggregate supply, for example, political mismanagement, armed conflict and trade wars, among others, trigger increases in the price of input goods and services. At a later stage, these processes could trigger an inflation driven by monetary causes since the trust in the sovereign currency could be undermined. In this last scenario, users reduce their money demand in a particular denomination because they think that this monetary asset does not properly fulfill the three functions of money. This could raise inflation expectations and hence reduce money demand, in other words, a sovereign currency would be gradually replaced by another currency. This money demand reduction may trigger long-term periods of high inflation and currency depreciation.

In Table 1 we can draw a distinction between two main categories of means of payment regarding the value: sovereign units of account and private units of account. The first category is the funds, which is defined in Directive (EU) 2015/2366 as banknotes and coins, scriptural money and electronic money. All these forms of means of payment have in something in common, they are either issued or guaranteed by a public authority and therefore they are denominated in sovereign units of account, for example, USD, EUR, JPY, CNY, et cetera. The second category is private digital currencies, which could be sub-categorized into virtual currencies and stablecoins. Virtual currencies are defined in Directive (EU) 2018/843 as a digital representation of value that is neither issued nor guaranteed by a public authority and is accepted as a mean of payment. For this reason, virtual currencies are denominated in their own private units of account, for example, BTC, ETH, et cetera. Stablecoins are also denominated in private units of account, for example, TUSD, LBR, et cetera. A higher money demand makes some means of payments more capable of serving as a store of value and for this reason they could reach the category of money. Nowadays, sovereign-denominated means of payments are considered as money while private-denominated means of payment do not fulfill, so far, the store-of-value function. As any asset in the economy, the means of payment could have a real nature or a financial nature. Any means of payment inherently bears two risks: fiat-value risk and operational risk. Fiat-value risk can be defined as the reduction of the value of the unit of account held by the user for the abovementioned reasons. Operational risk could be defined as the risk of suffering losses resulting from inadequate designs and technology failures. Additionally, in the fractional reserve banking system there are claim-like means of payment, for example, bank deposits and e-money which bear credit risk, which is defined as the possibility of suffering losses stemming from the issuer's failure to redeem the sight obligations. Public authorities' core tasks are to ensure confidence in money and in payment systems. The fiat-value risk is mitigated by the central bank monetary policy, the operational risk by payment systems oversight and credit risk by prudential and supervision regulation, the lender of last resort (LOLR) function and the deposit insurance schemes. On the other hand, cash and Bitcoin have a real 
nature, since they do not pose an obligation to convert them into another means of payment, and only bear operational and fiat-value risk.

As is shown in Table 1, the five means of payment can be issued either passively or actively. These different kinds of issuances will be further developed in Section 2.2 through sectoral balance sheet dynamics. A passive issuance means that money is issued in an amount determined by the users' money demand and without limits, as it is currently the case with cash and e-money. On the other hand, an active issuance must follow a certain rule, such as the rule of granting credit in the issuance of bank deposits, the monetary policy rule in central bank reserves and the predefined-mining rule in virtual currencies such as Bitcoin.

Regarding the rate of interest, some account-based means of payment can bear interest, whether it is a positive, a negative or zero interest rate. Bank deposits bear interest, virtual currencies could bear it and e-money cannot because it is prohibited under European Directives. Object-based money like cash could also bear it, but nowadays in all countries it is a non-interest-bearing means of payment.

\subsection{The Second Pillar: A Sectoral Balance Sheet Dynamics; The Creation and Destruction Process of Money and Other Means of Payment}

In this section we develop the issuance design feature in detail. A passive issuance means that money is issued in an amount determined by the user's money demand without limits. On the other hand, an active issuance must follow a certain rule. These issuances are studied through sectoral balance sheet dynamics based on double-entry bookkeeping principles. This approach is based on the following works: [4,13-15].

In our sectoral balance sheet dynamics, we start from a model that represents the current situation of five economic sectors which hoard, issue and transfer means of payment. The financial figures in the balance sheet of each sector broadly represent the Euro-area economy during 2019, but these figures are less important than the flow of funds. As is shown in Table A1 of the Appendix A, the first economic sector is the central bank (I), which is the first level participant in the current fractional reserve banking system. Central banks issue two means of payments, cash and reserves, and on the asset side they own international reserves, main refinancing operations (MRO) and public debt. Commercial banks (II) at a consolidated level are the second tier in the current system. They issue bank deposits, receive MRO funding from the central bank and are linked to foreign banks through a deposit and an asset account aimed at facilitating foreign trade and other cross border capital flows. On the asset side, commercial banks make loans, purchase public debt and use and hoard reserves. The third sector (III) is the government, which issues public debt and owns reserves in order to transfer funds in the context of the public spending. Households and companies (IV) demand money, mainly cash and bank deposits, own real assets as their main source of wealth and on the liability side, receive loans. The last sector is foreign commercial banks (V), which are linked to domestic banks. When analyzing e-money, stablecoins and virtual currencies, the fifth sector will be replaced by the e-money and private digital currency providers. The financial accounting of the flow of funds is implemented in one, two or several steps, and in quantities of 10, which will be represented as follows: $1(+10) 2(-10)$ and $3(+10) 2(-10) 4(+10)$, among others.

As was already mentioned in Section 2.1, in modern economies bank deposits are the most demanded means of payment. For this reason, in this section we focus on examining the main ways through which bank deposits are created. In Figure 1 we show the ECB's monthly monitoring of the broad money growth, which identifies the following three main types of active issuances or counterparts within the bank deposit creation and destruction process, in other words, three sources of money creation by commercial banks, Lending to households and companies, purchases of public debt and net external monetary flows. In March 2019 the money supply measured by the M3 broad money aggregate ( $€ 12.5$ trillion) primarily comprised bank overnight deposits ( $€ 7.3$ trillion) and, to a lower percentage, cash ( $€ 1.2$ trillion) and short-term deposits up to two years ( $€ 3.4$ trillion). When the ECB launched the asset purchase program (APP) in 2015, during a four-year period, the main source of 
money creation was purchases of public debt by commercial banks along with credit to the private sector, as Figure 1 shows. Once the ECB finalized its APP, the main contributors of bank deposits growth were net external flows and credit to the private sector. Today, due to the Great Lockdown caused by the COVID-19 pandemic, the main sources of money creation are credit to the private sector and purchases of public debt.

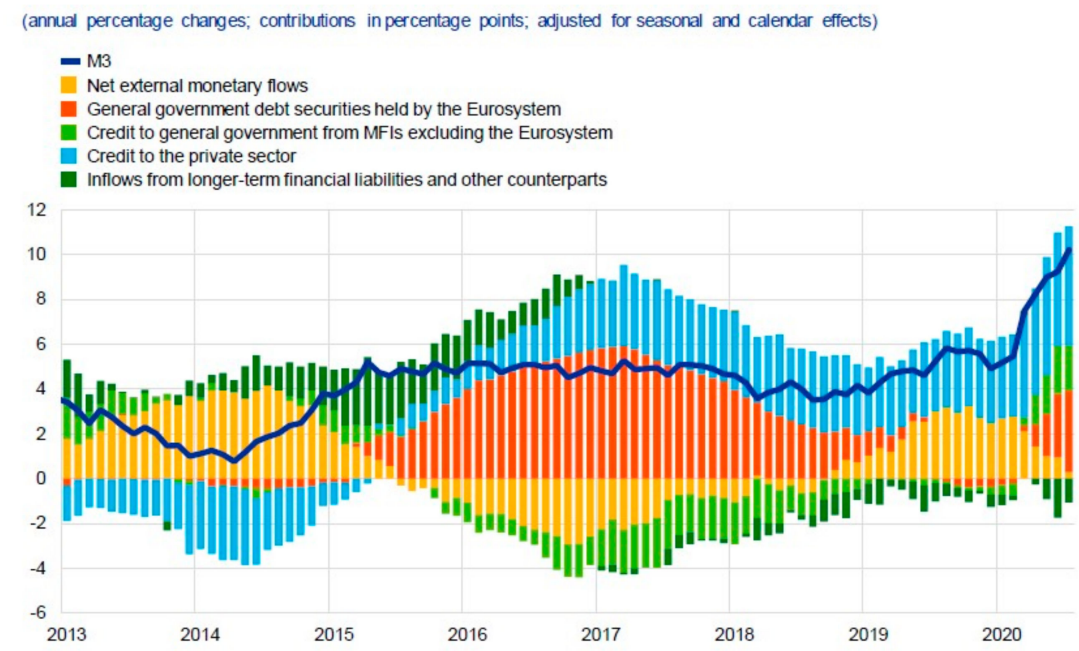

Figure 1. Counterparts of broad money creation (2013-2019). Source: ECB monthly monitoring of monetary aggregates. Issue 1/2020 Economic Bulletin.

The processes of money creation in the form of bank deposits are illustrated in Tables A2-A4. Table A2 shows how bank deposits are created in the process of bank lending. When commercial banks at a consolidated level make a loan they simultaneously create a matching deposit in the borrower's bank account and both the balance sheets of the private and the commercial banking sector increase [16] On the contrary, when that loan is repaid the new bank deposit is destroyed and both balance sheets decrease by the loaned amount.

In Table A3 we show how public debt purchases by banks create new deposits. In the first step, the government issues public debt that is purchased by commercial banks, which transfer central bank reserves to the government. In the second step, the government, with these new reserves borrowed, implements public spending increasing both the balance sheet of the commercial banks and the households and companies. Table A4 shows the money creation process regarding external monetary inflows. When a domestic company exports real assets in exchange for foreign currency, the domestic commercial bank's balance sheet increases while the foreign commercial banks replace the importer's deposit account with the domestic commercial bank's deposit account.

The creation process of cash follows a passive issuance rule. This issuance depends on the public demand of this type of money. When people demand cash, commercial banks also demand it from the central bank, which produce it and then issue it in exchange for reserves owned by commercial banks.

At the final stage of the system, users withdraw this cash in exchange for deposits, which decreases the balance sheet of commercial banks. Table A5 shows how e-money is passively issued by electronic money providers. These institutions increase their liabilities and assets to the same amount with the obligation of holding a reserve comprised by cash equivalents and short-term securities. Private institutions that issue stablecoins could do it, as shown in Table A6, either passively (step 1), in other words, in the same way as e-money providers, or actively (step 2) by granting long-term loans as commercial banks do. Finally, Table A7 shows the creation of actively-issued virtual currencies such as Bitcoin, in which miners use electrical power, which is a real asset, in order to create another real asset, the Bitcoin. 


\subsection{The Third Pillar: The Five Inherent Risks to the Current Fractional Reserve Banking System}

In this section we identify five inherent risks to the current fractional reserve banking system stemming from sudden shifts in money demand and supply. Money demand shifts can be split into two categories depending on whether they are driven by technological design features or by economic features. Since official coinage of metal-based money in ancient times, the deposit banking advent in the middle-ages and the eighteen-century with bank-cash issuances to the current rise of digital currencies, technological innovation has always transformed the payment landscape and has driven the shifts in the demand of different means of payment.

Nowadays, digitalization is changing the way we pay. Bank deposits and e-money have grown increasingly thanks to payment innovations such as smartphone apps and touchless credit and debit cards. People are increasingly substituting less technologically advanced means of payment for more advanced ones. This rapid substitution is particularly focused on cash, whose demand is decreasing in many countries and is being replaced by other means of payments, such as bank deposits and e-money. This has raised concerns among policy makers about a potential materialization of a risk of a cashless society. In line with the Bank of Canada's approach [17], we identify three adverse effects of a potential materialization of this risk: (i) the financial exclusion in emerging market economies(EME) and advanced market economies(AMEs) of unbanked and underbanked people; (ii) a payment concentration in bank deposits, which prevents people from paying and saving in a credit-risk-free means of payment; and (iii) a less effective monetary policy, since cash disappearance would reduce the central bank's balance sheet and the demand of reserves.

This digitalization trend could also disrupt the traditional bank-based ecosystem. E-money adoption could be fast due to its attractiveness, as is currently the case in China. A sudden replacement of bank deposit with e-money, stablecoins and virtual currencies could materialize a risk of structural bank disintermediation (II), which consists of a sudden contraction in bank credit to the real economy. This sudden contraction negatively impacts the business models of banks and borrowers, since both are used to operating with a certain amount of credit. Commercial banks would reduce its customer interaction [18], which reduces credit activity and hence their balance sheet, their profitability and increases the cost of their funding. The substitution of bank deposits for e-money and stablecoins could be assimilated into money market funds (MMF) and investment funds issuances, which disintermediates the banking system and plays an important role in interbank funding, as it is currently the case in US and China.

The active issuance of claim-like means of payment by commercial banks, in other words, bank deposits make them operate with a structural liquidity shortage, since they cannot convert all their overnight deposits into cash and into deposits in other banks on a one-to-one basis. A sudden migration from bank deposits to e-money and stablecoins would replace retail deposits, which are a stable source of funding, by wholesale deposits, which are a less stable source of funding. This could trigger a risk of systemic bank runs (III).

The second category of sudden shifts in money demand is related to the fiat-value design feature and hence with the unit of account of a means of payment. As mentioned in Section 2.1, nowadays all means of payment have a monetary value and hence money demand depends on trust in the issuer to keep this fiat value stable. This trust could be rapidly undermined for monetary and real causes and hence people could substitute means of payments denominated in domestic units of account for others denominated in foreign units of account in a gradual process known as official and unofficial dollarization [19]. This process could materialize a risk of currency substitution (IV), both domestically and internationally [20]. The main consequence of the potential materialization of this risk is the loss of the monetary sovereignty, which could trigger (i) long-term periods of high inflation, (ii) exchange rate depreciations, which would undermine the country's ability to import and export in its own currency [21] and hence increase the country's foreign-denominated debt, and (iii) a subordination to a foreign country's monetary policy. The currency substitution process is eased by fractional reserve banking systems, which are linked by international correspondent banks. 
There could be a second scenario of currency substitution, the one in which the sovereign currency is replaced by private digital currencies, such as Bitcoin and stablecoins [20]. In Europe and US, Facebook's issuance announcements [22,23] of its own fiat-backed digital currency, the stablecoin Libra, has raised concerns among authorities due to probable adverse impacts on monetary sovereignty in case this stablecoin is widely accepted. The second step of Table A6 shows how stablecoin providers would actively issue stablecoins by making loans if these means of payment would be used as a store of value and hence become widely accepted.

Regarding the sudden shifts in money supply, they are explained by the commercial banks' ability to create new bank-deposit money in the process of bank lending. This money creation process is the main cause of economic and financial bubbles risk $(\mathrm{V})$. In the current fractional reserve banking system, money creation mainly depends on banks' willingness to supply credit. Sudden changes in this willingness could trigger credit booms which profoundly distort the resources allocation process and, therefore, the productive and consumption structure, in other words, create financial and economic bubbles. These money creation processes finally stop because commercial banks face limits in their lending activity. When these bubbles finally burst, the economic activity collapses and innumerable adverse effects arise, such as high unemployment rates, GDP contractions and banking, currency and debt crises, as was the case during both the Great Recession and the Great Depression.

In this paper we assume that the main cause of the economic crisis is the overshooting of the money supply by commercial banks. In order to clarify this, we will make two main assumptions. First, economic crises are generally defined as a negative GDP annual growth rate for two consecutive quarters. The second assumption is that an economic crisis has two main causes: (i) exogenous factors, such as the Great Lockdown (COVID-19), wars, natural disasters, trade wars and secular stagnation, among others; and (ii) an endogenous factor, which is the current money creation process already described driven by commercial banks and which could have either a domestic or a foreign origin.

These assumptions are based on the following works: [1-3,24-26]. The work of Richard Vague is worth mentioning because he takes an in-depth look at all endogenous-economic crises since 1844. Specifically, he defines the endogenous cause of economic crisis as an increase in the private debt-to-GDP ratio by 18 percent accumulated over five years [27]. Moreover, if this ratio reaches 150 percent the risk of an economic crisis increases significantly.

\section{An Assessment of Several Central Bank Digital Currency Proposals}

\subsection{CBDCs as New Means of Payment that Would Complement Cash and Bank Deposits}

As mentioned in the introduction, central banks and academics have identified the risks of cashless societies and currency substitution stemming respectively from the decline in cash usage and the rise of private digital currencies. In order to mitigate these risks, many central banks are exploring the possibility of issuing domestic-retail CBDCs as a complement to cash and bank deposits. This would mean that for the first time in monetary history people could pay and save in a credit-risk-free digital currency. On the other hand, these CBDC issuances are going to challenge the current fractional reserve banking system and proponents also carefully weigh the costs of these issuances.

Both public authorities and academics consider several consequences stemming from a cashless society [6]. Among these consequences the following ones were highlighted: (i) the financial exclusion in EMEs and AMEs of low-income people, which do not have access to conventional banking systems; and (ii) a payment concentration in means of payment with credit risk, in other words, bank deposits and e-money, settled by conventional payment systems (e.g., Visa, MasterCard and Target 2) which would make the payment system increasingly vulnerable to banking crisis and would not allow people to save in a credit-risk-free money. A CBDC issuance would mitigate these consequences since they are built on alternative universally-accessible and credit-risk-free payment systems.

The rise of private digital currencies such as Bitcoin and Libra was another important trigger in the CBDC debate. In a scenario of private digital currencies increasingly demanded, a risk of currency 
substitution could be materialized [20]. A CBDC issuance could limit this risk due to people's higher trust, both for technological and economic reasons, on a credit-risk-free digital currency issued by the central bank.

Regarding the optimal design of a CBDC to limit these risks, there is no general agreement on the core features so central banks and academics are currently considering a wide range of CBDC variants.

By definition, a CBDC is a real monetary asset issued by the central bank and hence denominated in sovereign units of account. These basic design features defined by the Bank for International Settlements (BIS) [4] are shown in the second column of Table 2. In this sense, CBDC proposals would be differentiated in the following design features: The payment system, the issuance and the interest rate.

Table 2. CBDCs' design features in proposals aimed at complementing cash and bank deposits.

\begin{tabular}{ccccc}
\hline Design Features & $\begin{array}{c}\text { BIS General } \\
\text { Framework }\end{array}$ & E-Krona Project & $\begin{array}{c}\text { Bordo and Levin } \\
\mathbf{( 2 0 1 7 )}\end{array}$ & $\begin{array}{c}\text { Chinese Reform } \\
\mathbf{( 2 0 1 7 - 2 0 1 9 )}\end{array}$ \\
\hline Format & Account-based & Account-based & Account-based & Account-based \\
Payment System & Optional & $\begin{array}{c}\text { Direct Ledger } \\
\text { (DLT) }\end{array}$ & Both & Indirect Ledger \\
Value & EUR & SEK & USD & CHY \\
Nature & Real & Real & Real & Real \\
Issuance & Optional & Passive & Passive & Passive \\
Interest bearing & Optional & YES & YES & NO \\
\hline
\end{tabular}

The BIS also offers central banks different technological choices regarding the payment system [7]. The CBDC ecosystem could be based either on a direct ledger or on indirect ledgers. According to the BIS, when a CBDC is designed as a direct ledger in the central bank and the payment services are provided by public authorities, we are talking about a direct CBDC. If the payment services are provided on a public-private partnership with a direct ledger, the CBDC is hybrid. The BIS have also defined a synthetic CBDC, which is based on indirect ledgers and payment services are provided by the private sector. The key difference between hybrid CBDCs and synthetic CBDCs is that in the former an alternative payment system to the traditional banking must be created so that the new CBDC circulates, while in the synthetic CBDC the current payment systems with fractional money, in other words, bank-deposit money and e-money, are transformed into CBDC through setting a 100 percent minimum reserve requirement.

Apart from mitigating its objectives risks, CBDC proposals are going to challenge the current fractional reserve banking system, so central banks are also assessing the negative implications of these issuances. The most frequently raised issues are the implications for financial stability, which refer to the materialization of the risks of structural bank disintermediation and systemic bank runs. These risks stem from a sudden significant migration from bank deposits to CBDCs, since these two assets are a substitute means of payment. In order to limit these risks, central banks and academics are considering the following two design features [28]: (i) an unattractive interest rate, such as a non-remunerated and an under-remunerated CBDC; and (ii) a hybrid issuance rule, which is a mix between an active and a passive issuance where users would substitute CBDCs for bank deposits up to a certain amount. Both designs violate the uniformity's money principle, which states that all forms of money within the same unit of account must have one-to-one convertibility at face value. A third characteristic that could limit the demand for CBDCs could be a payment system design that only allows a limited number of payment services, for example, allowing P2P transfers but not allowing P2B card payments, electronic commerce or direct debits.

In the third column of Table 2 we show one of the most advanced projects on domestic-retail CBDC, the E-Krona Sweden proposal. This project has been studied for four years $[29,30]$ and is now in the pilot program stage. The Riksbank's main objective is to mitigate the risks of a cashless 
society and currency substitution. There are other CBDC pilot projects already finished, for example, the E-Peso proposal in Uruguay [31] and the E-Hryvnia in Ukraine [32], other pilot projects at the test stage, for example, the Chinese DC/EP-CBDC [33], and other CBDC projects in early stages [7,34]. The Chinese CBDC, the DC/EP, would be based on a direct ledger approach with an active participation of the private sector. The Bank of Canada [35] will develop its retail CBDC as a contingency plan, for the case when cash disappears or a private digital currency threatens the Canadian monetary sovereignty, and its payment system would be off-balanced and both are based on a direct and an indirect ledger approach.

Regarding the technical aspects, the Riksbank has developed a hybrid CBDC based on a payment system with the following two features: (i) there is a sole and direct DLT-ledger run by the central bank and (ii) payment services are provided on a public-private partnership, with a public digital wallet (smartphones, PC, etc.) which enables users to make deposits, payments and transfers. Authorized private payment providers could also integrate CBDCs into their applications and issue payment instruments. The platform has a core ledger run by the Riksbank and in which authorized private payment providers would jointly record all CBDC users' accounts and payment transfers. These technological designs imply a high degree of demand-side substitutability between bank deposits and CBDCs. Because CBDCs are credit-risk-free means of payments, a scenario where people significantly replace bank deposits with CBDCs would be highly likely. Table A8 shows how these substitutions would trigger a risk of structural bank disintermediation and a risk of systemic bank runs. In order to limit these risks, the Riksbank would design its CBDC with an interest rate [30], and will not apply any limitations on the E-Krona's volume per person, in other words, a hybrid issuance. A CBDC interest rate significantly lower than the deposit rate facility, which influences the interest rate on bank deposits, would discourage a migration from bank deposits to CBDCs.

In the E-Krona proposal, as in all CBDC proposals aimed at complementing cash and bank deposits, there is always a trade-off between low levels of (I), (IV) and (V) risks and high levels of (II) and (III) risks. This could also be defined as the CBDC dilemma, which states that in CBDC proposals aimed at complementing cash and bank deposits it is impossible to have both of the following at the same time: (1) low levels of (I), (IV) and (V) risks; and (2) low levels of (II) and (III) risks [36] put forward a CBDC issuance to complement cash and bank deposits with the objective of mitigating the risk of a cashless society and currency substitution. In order to limit the risks of structural bank disintermediation and systemic bank runs, the authors reject hybrid issuances and put forward an interest bearing CBDC with a two-tiered remuneration system. In this system there would be at least two CBDC rates: (i) up to a certain amount per person, tier-one-CBDC rate could be set to zero in order to fulfill the medium-of-exchange function of money; and (ii) above that amount, tier-two-CBDC rate could be negative in order to make it unattractive to save in $C B D C$, avoiding significant increases in the risks of structural bank disintermediation and systemic bank runs [37] have designed a CBDC proposal with a variable interest rate and with an issue amount determined by the central bank, in other words, an active issuance rule to limit the risks of structural bank disintermediation and systemic bank runs. In [38] the authors designed a hybrid CBDC issuance in which some frictions would be introduced to discourage large-scale runs to CBDCs, for example, imposing fees on unusually large balances and removing the requirements for banks to convert deposits to CBDCs $[39,40]$ have put forward, as is shown in column four of Table 2, a passively-issued interest-bearing CBDC proposal aimed at complementing cash and bank deposits. These authors focused on the monetary policy benefits and identify, among others: (i) enriching the monetary policy toolkit with an additional instrument, namely, the CBDC interest rate; (ii) overcoming the ZLB constraint, if combined with a cash phase-out; and (iii) capturing the fiscal revenue from money creation, the so-called seigniorage. The interest rate on CBDCs would not limit the risks of structural bank disintermediation and systemic bank runs since this rate would be the same as the deposit facility rate.

Moreover, the authors have not designed an issuance tool to limit the risks, in other words, an active or a hybrid issuance rule, and have designed a passively-issued CBDC instead, so in this 
proposal there would be no limit to large scale migrations from bank deposits to CBDCs. The authors suggest mitigating the risk of systemic bank runs with an unlimited implementation of the LOLR function. Given that the proposal would discourage and phase out the use of cash, the economy could benefit from negative interest rates [41]. In this scenario, the ZLB constraint would fall and a policy of interest rates cuts below zero would encourage consumption and investment. In a scenario with a full migration from bank deposits to CBDCs the commercial banking system would be disintermediated and the interest rate on CBDC would be directly applicable to households and companies. In this proposal CBDCs are issued in exchange for public debt instead of reserves, so in a scenario of a high CBDC demand the government must issue new public debt and the CBDC dilemma is between low levels of risks (I), (III), (IV), (V) and a low level of risk (II).

In the fifth column of Table 2 we show a particular CBDC issuance by the People's Bank of China (PBoC). During a two-year period, from 2017 to 2019, public authorities in China required Bigtechs-e-money issuers, namely, Alibaba and TenCent, to gradually adopt a 100 percent minimum reserve requirement in central bank reserves [42]. As it was analyzed by the IMF [9], this reform implied a synthetic CBDC issuance, in other words, an indirect and on balance sheet ledger approach, and turned these Bigtechs into narrow banks. The main aim of the PBoC's reform was to limit interlinkages between commercial banks and these Bigtechs operating as money market funds. While the reform limited these interlinkages, the PBoC created a structural shrink in the commercial bank balance sheet, as Table A9 shows. In the first step, the amount of bank deposits backing the Bigtechs' e-money is replaced by CBDCs, which implied a reduction in reserves and deposits within the commercial banks' balance sheet.

Because these CBDCs are non-interest bearing and passively issued, there is no limit on CBDC demand by users. The second step of Table A9 shows the effects of a migration from bank deposits to CBDC-backed e-money. In its second white paper, Facebook [23] put forward a single-currency stablecoin issuance, which would have the same design features as e-money since it would be a sovereign-denominated passively-issued and claim-like means of payment backed by cash equivalents and short-term securities. Moreover, Facebook has also proposed to public authorities a CBDC-backed e-money in the same way as the Chinese Bigtechs.

\subsection{CBDCs as New Means of Payment that Would Replace all Bank Deposits}

In this second group of CBDC proposals proponents aim at mitigating the dysfunctions of the fractional reserve banking system, in other words, the risks of systemic bank runs and economic and financial bubbles. As studied in Section 2.3, the bank-money creation process is the only cause of endogenous economic crisis. Commercial banks recurrently behave procyclically issuing bank deposits in processes of credit expansions, which disrupts the productive and consumption structure and overheats the economy. The proponents argue that CBDCs are an appropriate tool to improve financial stability and reduce banks' moral hazard by downscaling the role of the banking system in money creation. These CBDC proposals are under the umbrella of the full reserve banking proposals. For nearly two centuries, several economists have been putting forward monetary-financial reforms $[43,44]$ aimed at mitigating the risks of systemic bank runs and economic and financial bubbles by removing the ability of banks to create deposits in the process of making loans and, at the same time, analyzing the risks stemming from a rapid and full bank disintermediation, such as the rise of the shadow banks.

Nowadays, CBDCs are seen by some economists as the appropriate tool to implement these reforms by replacing all bank deposits with CBDCs, in other words, that the only digital currency in circulation would be CBDCs. As Table 3 shows, within full reserve banking proposals we differentiate between the two followings sets of approaches, in which CBDC issuances have the same design features except for the payment system: (i) narrow banking proposals, in which the existing payment systems based on fractional money would be converted into payment systems based on CBDC by requiring banks and e-money providers a 100 percent minimum reserve requirement, in other words, a passively issued synthetic CBDC, and (ii) sovereign money proposals, in which the existing and indirect payment 
systems would be replaced by a direct ledger run by the central bank and commercial banks and e-money providers would not issue any form of money, neither passively nor actively. In both sets of proposals the money creation process is taken over by central banks, which would actively issue all money supplied. When central banks get involved in activities such as determining the money supply growth and the provision of financial services, their independence could be at risk. For this reason, these sets of CBDC issuance proposals should establish mitigating measures of this risk, such as (i) fix rules to restrict the monetary authority's discretion for the growth of the money supply and (ii) indirect and synthetic CBDC schemes that would prevent central banks from providing payment and credit services.

Table 3. CBDCs' design features in proposals aimed at replacing all bank deposits.

\begin{tabular}{ccc}
\hline Design Features & $\begin{array}{c}\text { Narrow Banking Proposals } \\
\text { (Benes and Kumhof, 2012) }\end{array}$ & $\begin{array}{c}\text { Sovereign Money Proposals } \\
\text { (Huber and Robertson, 2000) }\end{array}$ \\
\hline Format & Account-based & Account-based \\
Payment system & Indirect ledger & Direct ledger \\
Value & EUR & EUR \\
Nature & Real & Real \\
Issuance & Active & Active \\
Interest bearing & NO & NO \\
\hline
\end{tabular}

The narrow banking proposals dates from nearly two hundred years when David Ricardo put forward his reform [45] to limit the active issuance of cash by private commercial banks and the risks associated, in other words, risks of systemic bank runs and economic and financial bubbles. A few years later this proposal became the 1844 Peel's Bank Act, which made the Bank of England the sole cash issuer and laid the foundation of the central banks and the current fractional reserve banking system. However, due to the consolidation of deposits issued by commercial banks as the major form of money, the risks of economic and financial bubbles and systemic bank runs persisted. In the twentieth century, several proposals were put forward in line with the spirit of the 1844 Peel's Bank Act reform [44,46-50], but none of them were implemented.

Most recently, economists Jaromir Benes and Michael Kumhof [26] revisited one of the previous proposals, the Chicago Plan, which is shown in the second column of Table 3. These authors see four major advantages in the proposal: ending recurrent economic cycles, a safer banking system, a reduction in debt dependence and a more effective monetary policy. Table A10 shows the immediate transition and subsequent functioning of the new full reserve banking system in the Chicago Plan Revisited reform. In a first step, the central bank would lend to commercial banks the specific CBDC amount in order to set a 100 percent CBDC minimum reserve requirement on bank deposits. This new liability in the commercial banking system could be used to offset their loans and public debt owned, lowering aggregate level of debt in the economy. In a second step, central banks would create the amount of CBDC money with an active issuance rule. This new CBDC money supply could be created by crediting the government account as public seigniorage revenue and then put into circulation by spending it, as steps two and three show.

The second group of studies is the sovereign money proposals, which aim at mitigating the same risks and see the same benefits as the narrow banking proposals. These proposals were initially put forward in 2000 by economists Joseph Huber and James Robertson [51] and were recently studied by others authors $[2,52,53]$. This reform would be implemented, as step one of Table A11 shows, by a substitution of all the deposits in the commercial bank's balance sheet for a conversion liability loaned by the central bank, which increases both the asset side of the central bank's balance sheet with a loan and the passive side with CBDCs.

As of that moment, current accounts would be detached from the commercial bank's balance sheet, creating a direct ledger in the central bank and, in the case of the participation of private payment providers, with multiples off-balance sheet ledgers. In the authors' views, the key to prevent banks 
from still creating new money is either by running off balance ledgers or with a direct ledger in the central bank since in narrow banking proposals commercial banks could still create new money by breaking the 100 percent minimum reserve requirement. We do not see any link between the accounting system design, in other words, on balance and off balance ledger, or the payments system approach, in other words, direct or indirect, and the creation of money, since in direct and off balance sheet ledgers any payment provider could create new money off balance sheet by digitally crediting a specific account with a certain amount. The only way to avoid fraudulent money creation in full reserve banking systems is either with a public-owned sole ledger payment system, in which the central bank provides all payment services, or with supervised private payment services providers. Steps two and three of Table A11, respectively, show how the new CBDCs created are credited in the government account as fiscal revenues and in the private sector account as a citizen dividend, also known as helicopter money [53]. In these last steps, the central bank would respectively purchase perpetual zero-coupon-state-issued bonds or exchange equity for $\mathrm{CBDC}$ on the liability side.

In these two groups of CBDC proposals aimed at replacing all bank deposits by CBDCs there is always a trade-off between a high level of (II) risk and low levels of the others risks. The CBDC dilemma would be between low levels of (I), (III), (IV) and (V), risks and low levels of (II) risk. In the fractional reserve banking system there is a high degree of maturity transformation due to the process of taking demand deposits and turning them into long-term loans and securities. If all deposits in the commercial banking system are replaced with CBDCs, this maturity transformation would be, at least during the first years after the reform, significantly lower. In this sense, the complete migration from bank deposits to CBDCs would fully and suddenly disintermediate the commercial banking system.

As studied in Section 2.3, this rapid disintermediation would negatively impact the business models of banks and borrowers, since both are used to operate with a certain amount of credit. We suggest that further research on CBDC should focus on this second group of proposals, which put forward CBDC transitions from a fractional reserve banking system to a full reserve banking system, with a phase-in approach aimed at also mitigating the risk of structural bank disintermediation and hence aimed at overcoming the CBDC dilemma. This gradually disintermediation of the commercial banking system would enable lenders and borrowers to adapt their business models to the new prices and quantities conditions in credit markets.

\section{Conclusions}

The future of money will take the form of an account-based digital currency and central banks are taking the lead and designing one of their own in a public-private partnership. In this paper we have set out a three-pillar monetary-financial framework to identify the trade-offs associated with changes in the demand and supply of the different means of payment, essentially with CBDCs.

In CBDC proposals aimed at complementing cash and bank deposits there is a CBDC dilemma which states that it is impossible to have both of the following at the same time: (1) low levels of (I), (IV) and (V), risks; and (2) low levels of (II) and (III) risks. On the other hand, in CBDC proposals aimed at replacing all bank deposits by CBDCs, the CBDC dilemma would be between low levels of (I), (III), (IV) and (V) risks and low levels of (II) risk.

We suggest that further research on CBDC should focus on the second group of proposals, which put forward CBDC transitions from the current two-tier fractional reserve banking system to a full reserve banking system, either direct or indirect ledger, with a phase-in approach aimed at also mitigating the risk of structural bank disintermediation and hence aimed at overcoming the CBDC dilemma. This gradually disintermediation of the commercial banking system would enable lenders and borrowers to adapt their business models to the new prices and quantities conditions in credit markets.

Author Contributions: The authors contributed equally to this work. All authors have read and agreed to the published version of the manuscript. 
Funding: This recearch reveived no external funding.

Acknowledgments: Carlos Viñuela would like to thank Miguel Ángel Fernández Ordóñez for his valuable comments and suggestions. The views expressed in this manuscript are those of the author and do not necessarily represent the views of Bank of Spain.

Conflicts of Interest: The authors declare no conflict of interest.

\section{Appendix A}

Table A1. Current two-tier fractional reserve banking system. Source: own elaboration.

\begin{tabular}{cccc}
\hline \multicolumn{1}{c}{ Assets } & \multicolumn{2}{c}{ Liabilities } \\
\hline Intern. Reserves & 724 & Central Bank & 1.231 \\
MRO & 734 & Reserves & 2.098 \\
Public debt & 2.899 & Others & 1.028 \\
& Commercial Banks (CBs) & \\
Reserves & 1.882 & Equity & 2.524 \\
Public Debt & 1.457 & Dep. of FS & 3.864 \\
Loans & 16.964 & Bank deposits & 22.702 \\
Dep. with FS & 4.626 & MRO & 734 \\
Others & 5.948 & Others & 1.053 \\
& \multicolumn{2}{c}{ Government } & Public debt \\
Reserves & 216 & Others & 9.898 \\
Others & 9.784 & Equity & 102 \\
& Households and Companies & 104.571 \\
Cash & 1.231 & Loans & 16.964 \\
Bank deposits & 22.702 & & \\
Real assets & 97.602 & Foreing Sector (FS) & Equity \\
Public debt & 5.542 & Foreing Deposits & 2.324 \\
FS Loans & 18.231 & Dep. of CBs & 4.626 \\
Dep. with CBs & 3.864 & & \\
\hline
\end{tabular}

Table A2. Active issuance of deposits by commercial banks making loans. Source: own elaboration.

\begin{tabular}{|c|c|c|c|c|c|}
\hline \multicolumn{3}{|c|}{ Assets } & \multicolumn{3}{|c|}{ Liabilities } \\
\hline \multicolumn{6}{|c|}{ Central Bank } \\
\hline Intern. Reserves & & 724 & Cash & & 1.231 \\
\hline $\mathrm{MRO}$ & & 734 & Reserves & & 2.098 \\
\hline Public debt & & 2.899 & Others & & 1.028 \\
\hline \multicolumn{6}{|c|}{ Commercial Banks (CBs) } \\
\hline Reserves & & 1.882 & Equity & & 2.524 \\
\hline Public Debt & & 1.457 & Dep. of FS & & 3.864 \\
\hline Loans & $1(+10)$ & 16.974 & Bank deposits & $1(+10)$ & 22.712 \\
\hline Dep. with FS & & 4.626 & MRO & & 734 \\
\hline Others & & 5.948 & Others & & 1.053 \\
\hline \multicolumn{6}{|c|}{ Government } \\
\hline Reserves & & 216 & Public debt & & 9.898 \\
\hline Others & & 9.784 & Others & & 102 \\
\hline \multicolumn{6}{|c|}{ Households and Companies } \\
\hline Cash & & 1.231 & Equity & & 104.571 \\
\hline Bank deposits & $1(+10)$ & 22.712 & Loans & $1(+10)$ & 16.974 \\
\hline Real assets & & 97.602 & & & \\
\hline \multicolumn{6}{|c|}{ Foreing Sector (FS) } \\
\hline Public debt & & 5.542 & Equity & & 2.324 \\
\hline FS Loans & & 18.231 & Foreing Deposits & & 20.687 \\
\hline Dep. with CBs & & 3.864 & Dep. of CBs & & 4.626 \\
\hline
\end{tabular}


Table A3. Active issuance of deposits by commercial banks purchasing debt. Source: own elaboration.

\begin{tabular}{|c|c|c|c|c|c|}
\hline \multicolumn{3}{|c|}{ Assets } & \multicolumn{3}{|c|}{ Liabilities } \\
\hline \multicolumn{6}{|c|}{ Central Bank } \\
\hline Intern. Reserves & & 724 & Cash & & 1.231 \\
\hline MRO & & 734 & Reserves & & 2.098 \\
\hline Public debt & & 2.899 & Others & & 1.028 \\
\hline \multicolumn{6}{|c|}{ Commercial Banks (CBs) } \\
\hline Reserves & $1(-10) ; 2(+10)$ & 1.882 & Equity & & 2.524 \\
\hline Public Debt & $1(+10)$ & 1.467 & Dep. of FS & & 3.864 \\
\hline Loans & & 16.964 & Bank deposits & $2(+10)$ & 22.712 \\
\hline Dep. with FS & & 4.626 & MRO & & 734 \\
\hline Others & & 5.948 & Others & & 1.053 \\
\hline \multicolumn{6}{|c|}{ Government } \\
\hline Reserves & $1(+10) ; 2(-10)$ & 216 & Public debt & $1(+10)$ & 9.908 \\
\hline Others & & 9.784 & Others & $2(-10)$ & 92 \\
\hline \multicolumn{6}{|c|}{ Households and Companies } \\
\hline Cash & & 1.231 & Equity & $2(+10)$ & 104.581 \\
\hline Bank deposits & $2(+10)$ & 22.712 & Loans & & 16.964 \\
\hline Real assets & & 97.602 & & & \\
\hline \multicolumn{6}{|c|}{ Foreing Sector (FS) } \\
\hline Public debt & & 5.542 & Equity & & 2.324 \\
\hline FS Loans & & 18.231 & Foreing Deposits & & 20.687 \\
\hline Dep. with CBs & & 3.864 & Dep. of CBs & & 4.626 \\
\hline
\end{tabular}

Table A4. Active issuance of deposits by commercial banks—capital inflow. Source: own elaboration.

\begin{tabular}{|c|c|c|c|c|c|}
\hline \multicolumn{3}{|c|}{ Assets } & \multicolumn{3}{|c|}{ Liabilities } \\
\hline \multicolumn{6}{|c|}{ Central Bank } \\
\hline Intern. Reserves & & 724 & Cash & & 1.231 \\
\hline $\mathrm{MRO}$ & & 734 & Reserves & & 2.098 \\
\hline Public debt & & 2.899 & Others & & 1.028 \\
\hline \multicolumn{6}{|c|}{ Commercial Banks (CBs) } \\
\hline Reserves & & 1.882 & Equity & & 2.524 \\
\hline Public Debt & & 1.457 & Dep. of FS & & 3.864 \\
\hline Loans & & 16.964 & Bank deposits & $1(+10)$ & 22.712 \\
\hline Dep. with FS & $1(+10)$ & 4.636 & $\mathrm{MRO}$ & & 734 \\
\hline Others & & 5.948 & Others & & 1.053 \\
\hline \multicolumn{6}{|c|}{ Government } \\
\hline Reserves & & 216 & Public debt & & 9.898 \\
\hline Others & & 9.784 & Others & & 102 \\
\hline \multicolumn{6}{|c|}{ Households and Companies } \\
\hline Cash & & 1.231 & Equity & & 104.571 \\
\hline Bank deposits & $1(+10)$ & 22.722 & Loans & & 16.964 \\
\hline Real assets & $1(-10)$ & 97.592 & & & \\
\hline \multicolumn{6}{|c|}{ Foreing Sector (FS) } \\
\hline Public debt & & 5.542 & Equity & & 2.324 \\
\hline FS Loans & & 18.231 & Foreing Deposits & $1(-10)$ & 20.677 \\
\hline Dep. with CBs & & 3.864 & Dep. of CBs & $1(+10)$ & 4.636 \\
\hline
\end{tabular}


Table A5. Passive issuance of e-money by private providers. Source: own elaboration.

\begin{tabular}{|c|c|c|c|c|c|}
\hline \multicolumn{3}{|c|}{ Assets } & \multicolumn{3}{|c|}{ Liabilities } \\
\hline \multicolumn{6}{|c|}{ Central Bank } \\
\hline Intern. Reserves & & 724 & Cash & & 1.231 \\
\hline MRO & & 734 & Reserves & & 2.098 \\
\hline Public debt & & 2.899 & Others & & 1.028 \\
\hline \multicolumn{6}{|c|}{ Commercial Banks (CBs) } \\
\hline Reserves & & 1.882 & Equity & & 2.524 \\
\hline Public Debt & & 1.457 & Bank deposits & & 22.702 \\
\hline Loans & & 16.964 & MRO & & 734 \\
\hline Others & & 5.657 & & & \\
\hline & & Gover & & & \\
\hline Reserves & & 216 & Public debt & & 9.898 \\
\hline Others & & 9.784 & Others & & 102 \\
\hline \multicolumn{6}{|c|}{ Households and Companies } \\
\hline Cash & & 1.231 & Equity & & 104.391 \\
\hline Bank deposits & $1(-10)$ & 22.272 & Loans & & 17.144 \\
\hline E-money & $1(+10)$ & 430 & & & \\
\hline Real assets & & 97.602 & & & \\
\hline \multicolumn{6}{|c|}{ E-Money Providers } \\
\hline Bank deposits & $1(+10)$ & 430 & E-Money & $1(+10)$ & 430 \\
\hline Loans & & 180 & Equity & & 180 \\
\hline
\end{tabular}

Table A6. Passive and active issuance of stablecoin by private providers. Source: own elaboration.

\begin{tabular}{|c|c|c|c|c|c|}
\hline \multicolumn{3}{|c|}{ Assets } & \multicolumn{3}{|c|}{ Liabilities } \\
\hline \multicolumn{6}{|c|}{ Central Bank } \\
\hline Intern. Reserves & & 724 & Cash & & 1.231 \\
\hline MRO & & 734 & Reserves & & 2.098 \\
\hline Public debt & & 2.899 & Others & & 1.028 \\
\hline \multicolumn{6}{|c|}{ Commercial Banks (CBs) } \\
\hline Reserves & & 1.882 & Equity & & 2.524 \\
\hline Public Debt & & 1.457 & Bank deposits & & 22.702 \\
\hline Loans & & 16.964 & $\mathrm{MRO}$ & & 734 \\
\hline Others & & & & & \\
\hline \multicolumn{6}{|c|}{ Government } \\
\hline Reserves & & 216 & Public debt & & 9.898 \\
\hline Others & & 9.784 & Others & & 102 \\
\hline \multicolumn{6}{|c|}{ Households and Companies } \\
\hline Cash & & 1.231 & Equity & & 104.391 \\
\hline Bank deposits & $1(-10)$ & 22.272 & Loans & $2(+10)$ & 17.154 \\
\hline Stablecoins & $1(+10) ; 2(+10)$ & 440 & & & \\
\hline Real assets & & & & & \\
\hline \multicolumn{6}{|c|}{ Global Stablecoins Providers } \\
\hline Bank deposits & $1(+10)$ & 430 & Stablecoins & $\begin{array}{c}1(+10) ; 2 \\
(+10)\end{array}$ & 440 \\
\hline Loans & $2(+10)$ & 190 & Equity & & 180 \\
\hline
\end{tabular}


Table A7. Active issuance of Bitcoin by miners (private providers). Source: own elaboration.

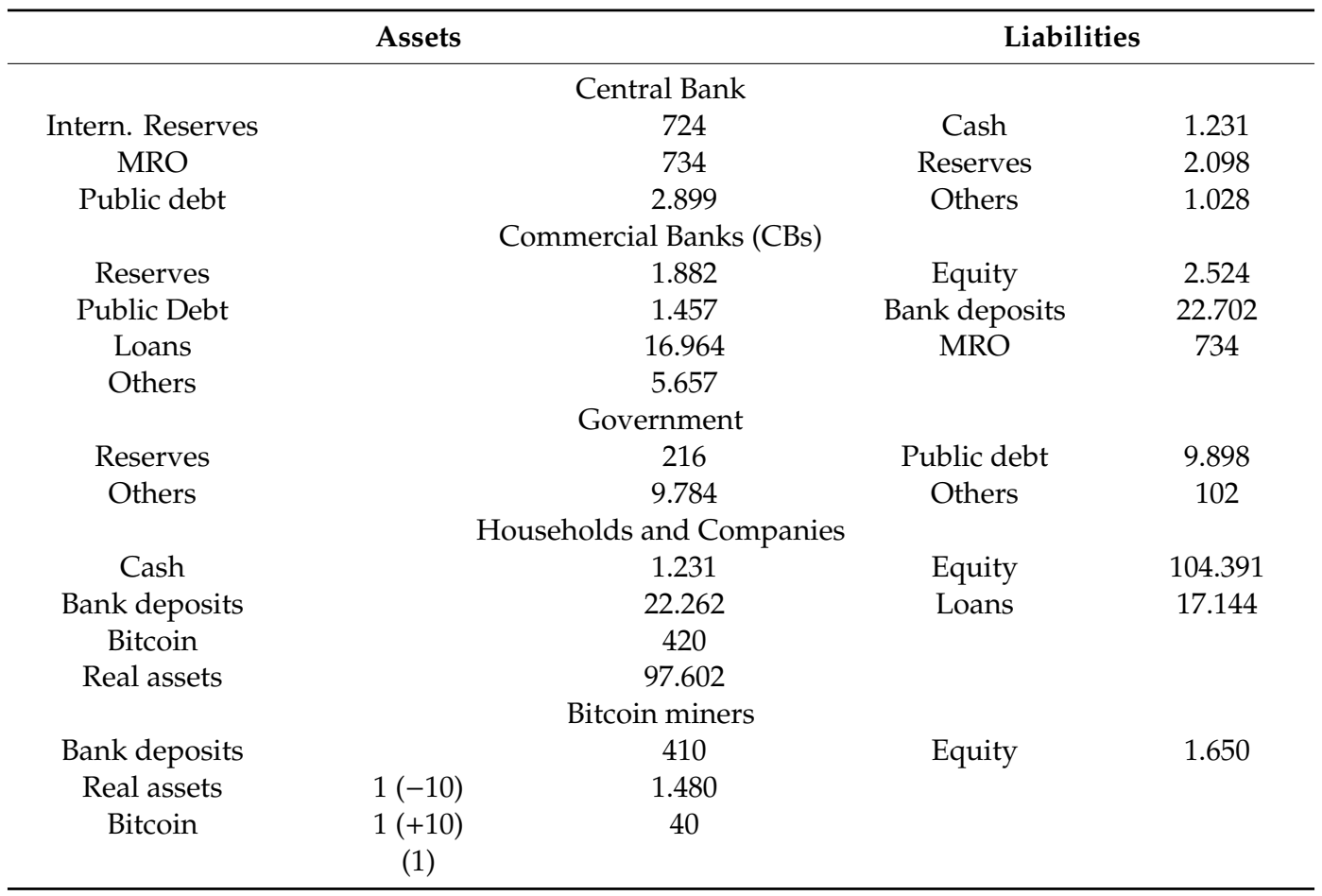

Table A8. The E-Krona issuance. Source: Own elaboration.

\begin{tabular}{|c|c|c|c|c|c|}
\hline \multicolumn{3}{|c|}{ Assets } & \multicolumn{3}{|c|}{ Liabilities } \\
\hline \multicolumn{6}{|c|}{ Central Bank } \\
\hline Intern. Reserves & & 810 & Cash & & 1.231 \\
\hline $\mathrm{MRO}$ & & 734 & Reserves & $1(-10)$ & 2.088 \\
\hline \multirow[t]{2}{*}{ Public debt } & & 2.899 & CBDC & $1(+10)$ & 96 \\
\hline & & & Others & & 1.028 \\
\hline \multicolumn{6}{|c|}{ Commercial Banks (CBs) } \\
\hline Reserves & $1(-10)$ & 1.872 & Equity & & 2.524 \\
\hline Public Debt & & 1.457 & Dep. of FS & & 3.864 \\
\hline Loans & & 16.964 & Bank deposits & $1(-10)$ & 22.692 \\
\hline Dep. with FS & & 4.626 & MRO & & 734 \\
\hline \multirow[t]{2}{*}{ Others } & & 5.948 & & & \\
\hline & & Gover & & & \\
\hline Reserves & & 216 & Public debt & & 9.898 \\
\hline Others & & 9.784 & Others & & 102 \\
\hline \multicolumn{6}{|c|}{ Households and Companies } \\
\hline Cash & & 1.231 & Equity & & 104.657 \\
\hline Bank deposits & $1(-10)$ & 22.692 & Loans & & 16.964 \\
\hline CBDC & $1(+10)$ & 96 & & & \\
\hline Real assets & & 97.602 & & & \\
\hline \multicolumn{6}{|c|}{ Foreing Sector (FS) } \\
\hline Public debt & & 5.542 & Equity & & 2.324 \\
\hline FS Loans & & 18.231 & Foreing Deposits & & 20.687 \\
\hline Dep. with CBs & & 3.864 & Dep. of CBs & & 4.626 \\
\hline
\end{tabular}


Table A9. Chinese Bigtechs' reform (2017-2019). Source: own elaboration.

\begin{tabular}{|c|c|c|c|c|c|}
\hline \multicolumn{3}{|c|}{ Assets } & \multicolumn{3}{|c|}{ Liabilities } \\
\hline \multicolumn{6}{|c|}{ Central Bank } \\
\hline Intern. Reserves & & 724 & Cash & & 1.231 \\
\hline \multirow[t]{2}{*}{$\mathrm{MRO}$} & & 734 & Reserves & $1(-420) ; 2(-10)$ & 1.668 \\
\hline & & & CBDC & $1(+420) ; 2(+10)$ & 430 \\
\hline \multirow[t]{2}{*}{ Public debt } & & 2.899 & Others & & 1.028 \\
\hline & \multicolumn{5}{|c|}{ Commercial Banks (CBs) } \\
\hline Reserves & $1(-420) ; 2(-10)$ & 1.452 & Equity & & 2.524 \\
\hline Public Debt & & 1.457 & Bank deposits & $1(-420) ; 2(-10)$ & 22.272 \\
\hline Loans & & 16.964 & $\mathrm{MRO}$ & & 734 \\
\hline Others & & & & & \\
\hline \multicolumn{6}{|c|}{ Government } \\
\hline Reserves & & 216 & Public debt & & 9.898 \\
\hline Others & & 9.784 & Others & & 102 \\
\hline \multicolumn{6}{|c|}{ Households and Companies } \\
\hline Cash & & 1.231 & Equity & & 104.391 \\
\hline Bank deposits & $2(-10)$ & 22.272 & Loans & & 17.154 \\
\hline E-money & $2(+10)$ & 430 & & & \\
\hline Real assets & & 97.612 & & & \\
\hline \multicolumn{6}{|c|}{ Bigtechs E-Money Providers } \\
\hline Bank deposits & $1(-420)$ & 0 & Equity & & 180 \\
\hline CBDC & $1(+420) ; 2(+10)$ & 430 & E-Money & $2(+10)$ & 430 \\
\hline Loans & & 180 & & & \\
\hline
\end{tabular}

Table A10. Active CBDC issuance in a narrow banking system. Source: own elaboration.

\begin{tabular}{|c|c|c|c|c|c|}
\hline \multicolumn{3}{|c|}{ Assets } & \multicolumn{3}{|c|}{ Liabilities } \\
\hline \multicolumn{6}{|c|}{ Central Bank } \\
\hline Perpetual Debt & $2(+10)$ & 112 & Cash & & 1.231 \\
\hline $\mathrm{MRO}$ & $1(+20,820)$ & 21.554 & CBDC & $1(+20,820) ; 2(+10)$ & 22.918 \\
\hline Public debt & & 2.899 & Others & & 416 \\
\hline \multicolumn{6}{|c|}{ Commercial Narrow Banks } \\
\hline CBDC & $1(+20,820) ; 3(+10)$ & 22.712 & Equity & & 2.524 \\
\hline Public Debt & & 1.457 & Bank deposits & $3(+10)$ & 22.712 \\
\hline Loans & & 16.964 & $\mathrm{MRO}$ & $1(+20,820)$ & 21.554 \\
\hline Others & & 5.657 & & & \\
\hline \multicolumn{6}{|c|}{ Government } \\
\hline CBDC & $2(+10) ; 3(-10)$ & 216 & Public debt & & 9.898 \\
\hline \multirow[t]{3}{*}{ Others } & & 9.942 & Perpetual Debt & $2(+10)$ & 112 \\
\hline & & & Others & $3(-10)$ & 148 \\
\hline & \multicolumn{5}{|c|}{ Households and Companies } \\
\hline Cash & & 1.231 & Equity & $3(+10)$ & 104.401 \\
\hline Bank deposits & $3(+10)$ & 22.272 & Loans & & 17.144 \\
\hline Real assets & & 98.042 & & & \\
\hline
\end{tabular}


Table A11. Active CBDC issuance in a sovereign money system. Source: Own elaboration.

\begin{tabular}{|c|c|c|c|c|c|}
\hline \multicolumn{3}{|c|}{ Assets } & \multicolumn{3}{|c|}{ Liabilities } \\
\hline \multicolumn{6}{|c|}{ Central Bank } \\
\hline Perpetual Debt & $2(+10)$ & 122 & Cash & & 1.231 \\
\hline MRO & $1(+22,702)$ & 23.436 & CBDC & $1(+22,702) ; 2(+10) ; 3(+10)$ & 24.380 \\
\hline Public debt & & 2.899 & Others & $3(-10)$ & 846 \\
\hline \multicolumn{6}{|c|}{ Payment Services Providers } \\
\hline CBDC & & 1.882 & Equity & & 2.524 \\
\hline Public Debt & & 1.457 & Bank deposits & $1(-22,702)$ & 0 \\
\hline Loans & & 16.964 & MRO & $1(+22,702)$ & 23.436 \\
\hline Others & & 5.657 & & & \\
\hline \multicolumn{6}{|c|}{ Government } \\
\hline CBDC & $2(+10)$ & 226 & Public debt & & 9.898 \\
\hline Others & & 9.896 & Perpetual Debt & $2(+10)$ & 122 \\
\hline & & & Others & & 102 \\
\hline \multicolumn{6}{|c|}{ Households and Companies } \\
\hline Cash & & 1.231 & Equity & $3(+10)$ & 104.401 \\
\hline Bank deposits & $1(-22.262)$ & 0 & Loans & & 17.144 \\
\hline CBDC & $1(+22,262) ; 3(+10)$ & 22.272 & & & \\
\hline Real assets & & 98.042 & & & \\
\hline
\end{tabular}

\section{References}

1. Turner, A. Between Debt and the Devil: Money, Credit, and Fixing Global Finance; Princeton University Press: Princeton, NJ, USA, 2015.

2. Fernandez-Ordoñez, M.A. Adiós a Los Bancos; Taurus: Mississauga, ON, Canada, 2020.

3. Vague, R. A Brief. History of Doom Two Hundred Years of Financial Crises; University of Pennsylvania Press: Philadelphia, PA, USA, 2019.

4. Cœuré, B.; Loh, J. Central Bank Digital Currencies; Technical Report; Bank for International Settlements: Basel, Switzerland, 2018.

5. Barrdear, J.; Kumhof, M. The Macroeconomics of Central Bank Issued Digital Currencies; Technical Report 605; Bank of England: London, UK, 2016. [CrossRef]

6. Boar, C.; Holden, H.; Wadsworth, A. Impending Arrival-A Sequel to the Survey on Central Bank Digital 621 Currency; Technical Report 107; Bank for International Settlements: Basel, Switzerland, 2020.

7. Auer, R.; Böhme, R. The technology of retail central bank digital. BIS Q. Rev. 2020, 1, 85-100.

8. Juškaite, A.; Šiaudinis, S.; Reichenbachas, T. CBDC-in a Whirlpool of Discussion; Technical Report 29; Liletuvos Bankas: Vilnus, Lithuania, 2019.

9. Adrian, T.; Mancini Griffoli, T. The Rise of Digital Money; Technical Report; International Monetary Fund: Washington, DC, USA, 2019.

10. Auer, R.; Cornelli, G.; Frost, J. Covid-19, Cash, and the Future of Payments; Technical Report; Bank for International Settlemens: Basel, Switzerland, 2020.

11. Krugman, P.R.; Obstfeld, M.; Melitz, M.J. International Trade: Theory E policy; Pearson Education Limited: London, UK, 2018.

12. Simmel, G. The Philosophy of Money; Routledge and Kegan Paul Ltd: Abington, UK, 1978.

13. Bindselil, U. An Introduction to Central Banking. Lecture Notes; European Central Bank: Frankfurt, Germany, 2018. [CrossRef]

14. Mcleay, M.; Radia, A.; Thomas, R. Money in the modern economy: An introduction. Bank Engl. Q. Bull. 2014, Q1, 14-27.

15. Gross, M.; Siebenbrunner, C. Money Creation in Fiat and Digital Currency Systems; Technical Report; International Monetary Fund: Washington, DC, USA, 2019. [CrossRef]

16. Lavoie, M. Post-Keynesian Economics: New Foundations; Edward Elgar Publishing: Cheltenham, UK, 2014.

17. Engert, W.; Fung, B.S.C.; Hendry, S. Is a Cashless Society Problematic? Technical Report 2018-12; Bank of Canada: Ottawa, ON, Canada, 2018. 
18. Hernández, P. Finance and technology: A brief history. In Financial Technology: The 150-Year Revolution; Technical Report; Bank for International Settlements: Basel, Switzerland, 2019.

19. Borensztein, E.; Berg, A. The Pros and Cons of Full Dollarization; Technical Report 50; International Monetary Fund: Washington, DC, USA, 2000. [CrossRef]

20. G7 Working Group on Stablecoins. Investigating the Impact of Global Stablecoins; Technical Report; Bank for International Settlements: Basel, Switzerland, 2019.

21. Ghosh, A.R.; Ostry, J.D.; Qureshi, M.S. Taming the Tide of Capital Flows; MIT Press: Cambridge, MA, USA, 2018.

22. Libra Association. An Introduction to Libra; Technical Report; Libra Association: Geneva, Switzerland, 2019.

23. Libra Association. White Paper v2.0; Technical Report; Libra Association: Geneva, Switzerland, 2020.

24. Lo Duca, M.; Koban, A.; Basten, M.; Bengtsson, E.; Klaus, B.; Kusmierczyk, P.; Lang, J.; Detken, C.; Peltonen, T. A New Database for Financial Crises in European Countries; Technical Report; European Systemic Risk Board: Frankfurt, Germany, 2017. [CrossRef]

25. Laeven, L.; Valencia, F. Systemic banking crises database. IMF Econ. Rev. 2013, 61, 225-270. [CrossRef]

26. Benes, J.; Kumhof, M. The Chicago Plan Revisited; Technical Report 202; International Monetary Fund: Washington, DC, USA, 2012. [CrossRef]

27. Vague, R. The Next Economic Disaster Why It's Coming and How to Avoid It; University of Pennsylvania Press: Philadelphia, PA, USA, 2014.

28. Bank of England. Central Bank Digital Currency. Opportunities, Challenges and Design; Technical Report; Bank of England: London, UK, 2020.

29. Sveriges Riksbank. The Riksbank's e-Krona Project. Report 1; Technical Report; Sveriges Riskbank: Stockholm, Sweden, 2017.

30. Sveriges Riksbank. The Riksbank's e-Krona Project. Report 2; Technical Report; Sveriges Riskbank: Stockholm, Sweden, 2018.

31. Ponce, J. Central bank digital currencies: A central banker perspective (e-Peso project in Uruguay our remark). In Analytical Report on the E-hryonia Pilot Project, Proceedings of the SUERF Conference "Do We Need Central Bank Digital Currency? Economics, Technology and Psychology", Milan, 7 June 2018; Technical Report; National Bank of Ukraine: Kiev, Ukraine, 2019.

32. Binance Research. First Look: China's Central Bank Digital Currency; Technical Report; Binance Research, 2019.

33. European Central Bank. Exploring Anonymity in Central Bank Digital Currencies; Technical Report; European Central Bank: Frankfurt, Germany, 2019.

34. Bank of Canada. Contingency Planning for a Central Bank Digital Currency; Technical Report; Bank of Canada: Ottawa, ON, Canada, 2020.

35. Bindseil, U. Tiered CBDC and the Financial System; Technical report; European Central Bank: Frankfurt, Germany, 2020.

36. Kumhof, M.; Noone, C. Central Bank Digital Currencies-Design Principles and Balance Sheet Implications; Technical Report 725; Bank of England: London, UK, 2018. [CrossRef]

37. Meaning, J.; Barker, J.; Clayton, E.; Dyson, B. Broadening Narrow Money: Monetary Policy with a Central Bank Digital Currency; Bank of England Staff Working Paper No. 724; Bank of England: England, UK, 2018.

38. Bordo, M.; Levin, A. Central Bank Digital Currency and the Future of Monetary Policy; Technical Report; National Bureau of Economic Research: Cambridge, MA, USA, 2017. [CrossRef]

39. Bordo, M.; Levin, A.T. U.S. Digital Cash: Principles E Practical Steps; Technical Report; Hoover Institution: Stanford, CA, USA, 2019.

40. Rogoff, K.S. The Curse of Cash: How Large-Denomination Bills Aid Crime and Tax Evasion and Constrain Monetary Policy; Princeton University Press: Princeton, NJ, USA, 2017.

41. Bank for International Settlements. III. Big Tech in Finance: Opportunities and Risks; BIS Annual Economic Report 2019; Bank for International Settlements: Basel, Switzerland, 2019; pp. 55-80.

42. Lainà, P. Proposals for full-reserve banking: A historical survey from David Ricardo to Martin Wolf. Econ. Thought 2015, 4, 1-19.

43. Phillips, R.J. The Chicago Plan. E New Deal Banking Reform; Routledge: Abington, UK, 1995.

44. Zarlenga, S.A. Lost Science of Money; American Monetary Institute: Valatie, NY, USA, 2002.

45. Fisher, I. 100\% Money; Adelphi Publication: New York, NY, USA, 1935.

46. Allais, M. L'impot sur le Capital et la Reforme Monétaire; Herman: Paris, France, 1988. 
47. Friedman, M. A monetary and fiscal framework for economic stability. Am. Econ. Rev. 1948, 38, $245-264$. [CrossRef]

48. Soddy, F. Wealth, Virtual Wealth and Debt: The Solution of the Economic Paradox; Britons Publishing Company: London, UK, 1933.

49. Tobin, J. Financial innovation and deregulation in perspective. In Proceedings of the BOJ Monetary and Financial Studies, Tokyo, Japan, 29-31 May 1985; pp. 19-29.

50. Huber, J.; Robertson, J. Creating New Money: A Monetary Reform for the Information Age; New Economics Foundation: London, UK, 2000.

51. Dyson, B.; Hodgson, G.; Lerven, F.V. Sovereign Money. An introduction; Technical Report; Positive Money: London, UK, 2016.

52. Huberman, G.; Leshno, J.D.; Moallemi, C.C. Monopoly Without a Monopolist: An Economic Analysis of the Bitcoin Payment System; Technical Report; Bank of Finland: Helsinki, Finland, 2017. [CrossRef]

53. Dyson, B.; Hodgson, G. Digital Cash. Why Central Banks Should Start Issuing Electronic Money; Positive Money: London, UK, 2016.

Publisher's Note: MDPI stays neutral with regard to jurisdictional claims in published maps and institutional affiliations.

(C) 2020 by the authors. Licensee MDPI, Basel, Switzerland. This article is an open access article distributed under the terms and conditions of the Creative Commons Attribution (CC BY) license (http://creativecommons.org/licenses/by/4.0/). 